\title{
STUDENTS` OPINION ON THE ACADEMIC CURRICULUM IN MILITARY CLASSES
}

\author{
Ilona URYCH, PhD \\ i.urych@akademia.mil.pl \\ Faculty of National Security \\ War Studies University, Warsaw, Poland
}

\begin{abstract}
This article includes the results of the author's research into the curriculum in military classes in the opinion of student class participants. The below study looks at the results of pilot studies implementing a diagnostic survey, the technique of the survey and a research tool such as the author's questionnaire with scaling.

The study consists of an introduction discussing education in military classes, the methodology of the research and the characteristics of the students as well as a preliminary assessment of the curriculum in military classes. The summary includes answers to the posed research problems and conclusions for further study based upon them.
\end{abstract}

Keywords: education, curriculum, youth, military classes, uniform classes

\section{Introduction}

Military classes include junior and senior secondary school classes implementing, broadly speaking, the curriculum of security education enriched with themes connected to the country's defence, the history of the Polish military and promoting patriotic behaviour in children and young people. The curriculum objectives and content is wide, showing a connection to the army and offering support to young people and to teachers` fascination. The curriculum content is rich and thanks to 
the support of educational authorities and the local community students can be offered practice. There are schools which employ passionate people, theoreticians and practitioners, teachers, alumni and their students. They integrate with the local community through their activity and shape their patriotic, civil and social attitudes.

Modern analysis of documents regulating the formation of military classes defines how the curriculum is implemented based on paedagogical innovation. In order to implement the curriculum, a teacher should be innovative and follow the curriculum based on the minimum requirement introduced by the Ministry of National Defence and entitled Minimum curriculum implemented as part of innovative programmes of military training or education for defence and training programmes of the non-government organisations required to sign agreements with the commander of a military school or training centre. More information about the functioning of military classes in Poland can be found in Urych (2016, pp. 112-134), Urych (2017, pp. 21-47), Urych (2017, pp. 148-177).

The next step for starting a military class is the procedure for implementation of innovation when a meeting of teachers makes a resolution to institute the innovation presented by one teacher. The resolution and description of the rules of innovation and the opinion of the school board (if there is no such board, the opinion of a meeting of teachers is presented) and the consent of the author (authors) are transmitted by the school principal to the educational officer and the school authorities by 31 March of the year preceding the academic year in which introduction of the innovation is planned. If the innovation requires the school being allocated additional resources, the written consent of the leading authority for the funding of the planned activity is required ${ }^{1}$.

Paedagogical innovation enables the introduction of subject or subjects with military content, most often consistent with the currriculum specific for a given school, generating programmes with various objectives, the quality and number of hours (maximum 3 hours a week). This is the reason why some classes have the engagement of teachers, students and their parents, the local community and the cooperation of a local military unit. Others are much less active. Anyway, military classes have been dynamically developing in Poland since the 1990s and enjoy the interest and acceptance of parents, teachers and the local community.

1 More on the possibility to implement paedagogical innovation in military education see Urych and Kanarski (2015, pp 62-75). 
While considering the need for systematic empirical research concerning the functioning of military classes, the Warsaw Academy of Military Art conducts studies on the problems of military classes in secondary education. ${ }^{2}$ One element of these studies concerns the school curriculum in military classes.

This article includes the results of the author's study on the curriculum in military classes in the opinion of students of these classes. The study looks at the methodology of the research and the characteristcs of the surveyed youth followed by preliminary assessment of the curriculum in military classes, their peculiarity and objectives as well as assessment of the characteristics young people involved in those classes. In its conclusion, the author answers the problems he had discussed and formulates propositions for further study.

\section{Methodology of the study}

The object of the study was the curriculum in military classes. The aim of the study was to describe the curriculum of military classes. The theoretical aim of the study was to enrich the system of theoretical paedagogical knowledge about education in military classes. The practical aim was to create, based on the obtained results, a research tool, a questionnaire for the survey to study the curriculum in military classes in the opinion of the students of these classes and also, prospectively, their teachers.

The main problem in the empirical study was the question: What are the characteristics of the curriculum in military classes? The following specific problems were defined:

1. What are the specific characteristics of the curriculum in military classes in the opinion of the surveyed students?

2. What are the aims of the curriculum in military classes in the opinion of the surveyed students?

2 Studies mentioned above have been conducted since 2014 in the Faculty of National Security and earlier in the Institute for Education for Security in the Academy of National Defence, and now in the Chair of Education for Defence in the Academy of Military Art. 
3. What are the characteristics of the students of military classes using the researched curriculums in the opinion of the surveyed students?

The method of diagnostic survey was used in the study (Pilch and Bauman 2001, pp. 79-82, Łobocki 2006, pp. 243-272). The applied research technique was a survey and the research tool was the author's questionnaire prepared for the survey with scaling: „The questionnaire for the survey for the students of military classes". The research was conducted in January and February 2017. The conducted research had a probationary (Jakubowska 1993, p. 112), experimental character, because it involved among other things: preliminary analysis of the results allowing information about some tendencies and lines of the researched relationships to be obtained; specifying knowledge about the environment which will be systematically studied; testing the usefulness of the prepared research vehicle that is a questionnaire prepared for the survey, namely the correctness of the prepared questions, the range of problems tackled, and the communications and instructions used in the vehicle. The character of the research was the reason why it included only a small group of students of military classes in secondary schools (200). The selection of the study group was random; however, the studied schools were chosen by lots among secondary schools with a so-called military profile which had signed agreements of cooperation with the Academy of Military Art in Warsaw. There were 200 students of military classes in the study, among which $54.5 \%$ were men and $45.5 \%$ women (Fig 1 ).

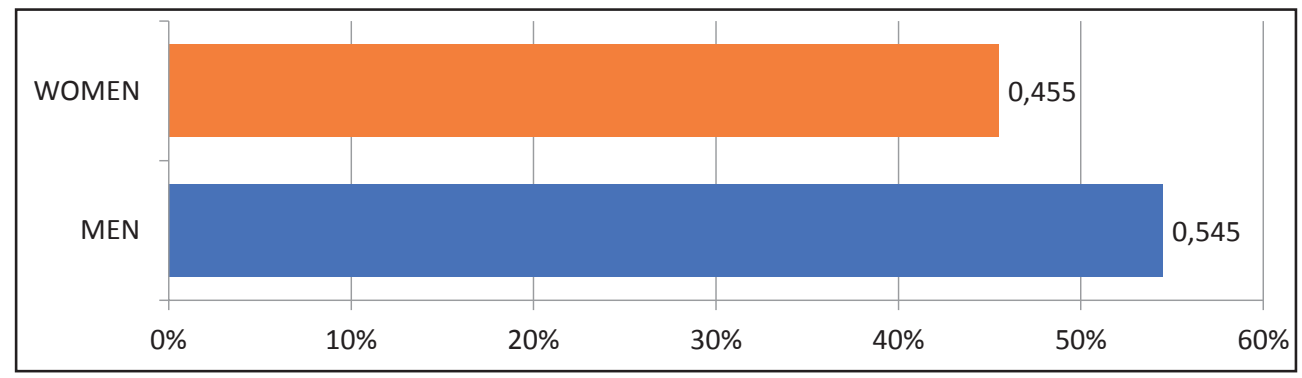

Fig.1. Characteristics of the gender of the researched group

The surveyed students were: the first grade $39.5 \%$, second grade $36.5 \%$ and third grade $24 \%$ (Fig 2). 


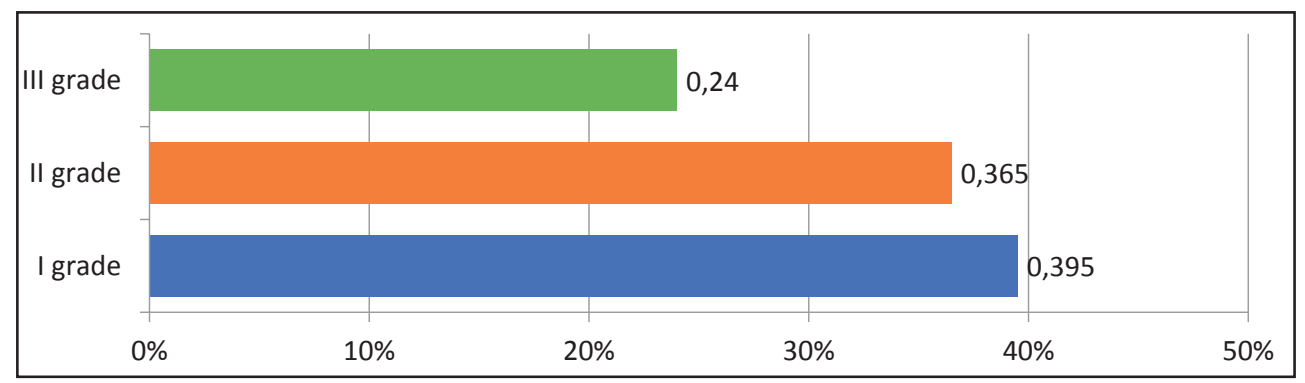

Fig. 2. Characteristics of the surveyed students with reference to education level

The surveyed students went to schools in various places with a different number of inhabitants: up to $500010 \%, 5-20$ thousand 25\%, 20-50 thousand 22.5\%, 50-100 thousand $22.5 \%$, over 100 thousand $20 \%$.

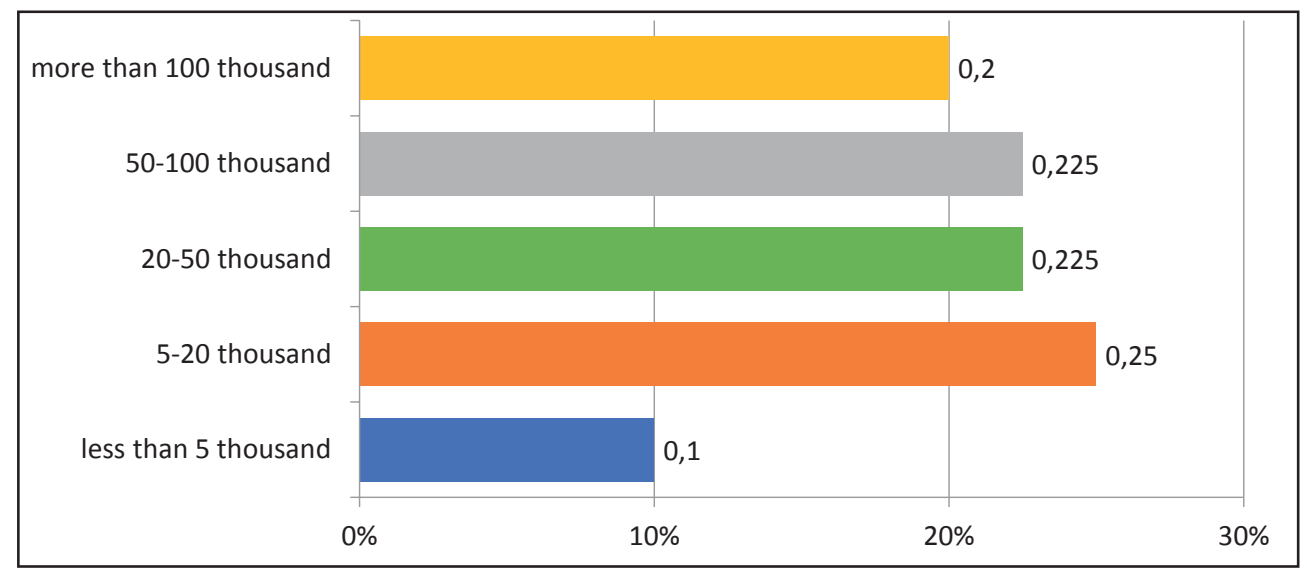

Fig. 3. Characteristics of the surveyed students with reference to places with various numbers of inhabitants

The study also made it possible to characterise the surveyed young people with respect to military traditions in their families. The result of the analysis proves that military traditions were passed in $62 \%$ of surveyed families. In the other $38 \%$ of cases, no one in the family was in the military. Most frequently, the uniform was worn by an uncle (29\%), grandfather (28.5\%), father $(22.5 \%)$ and in single cases mother $(2 \%)$ or more distant relatives $(8 \%)$, which is represented in Figure 4. 


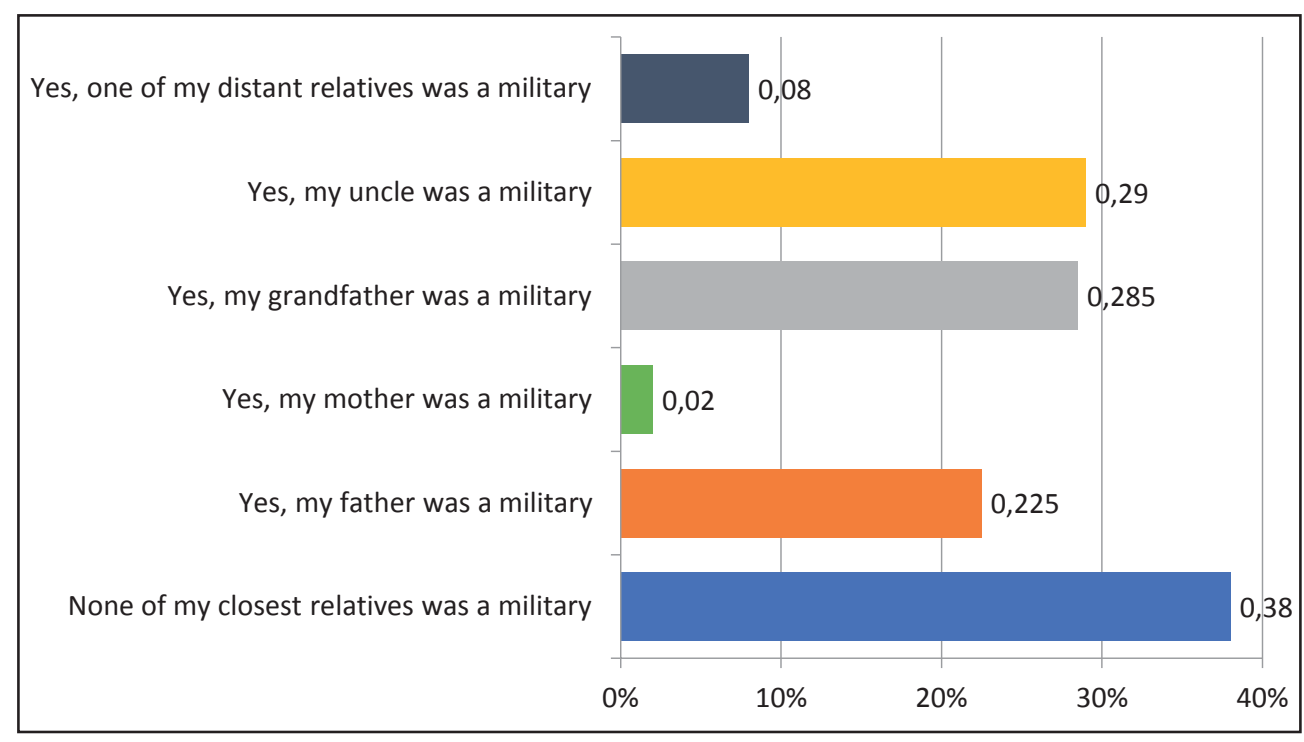

Fig. 4. Characteristics of the surveyed students respective of family military traditions

\section{Specific school curriculum in military classes in the opinion of the respondents}

According to the surveyed students, what is characteristic for the curriculum of uniformed classes is wearing a uniform $80.5 \%$, and in the area of education: classes in military drill $76.5 \%$, prevention and military discipline $74.5 \%$, military service $72.5 \%$. The surveyed students also mentioned that they participate in national festivities $70 \%$, shooting training $66 \%$, they go to military camps $65.5 \%$ and to the training in a military unit $65 \%$. Military classes are partly conducted by the military $65 \%$. There is cooperation with a military unit $61 \%$ and shooting unit 43\%. Students of uniformed classes learn national and regional traditions $49.5 \%$. The curriculum includes extra training 56.5\% and medical training 39\%, more physical training 35.5\%, history and Social Studies [WOS] 29.5\%, geography 28\%, IT $6.5 \%$. The surveyed students generally declared that they had more hours than students in other profiled classes (Fig 5). 


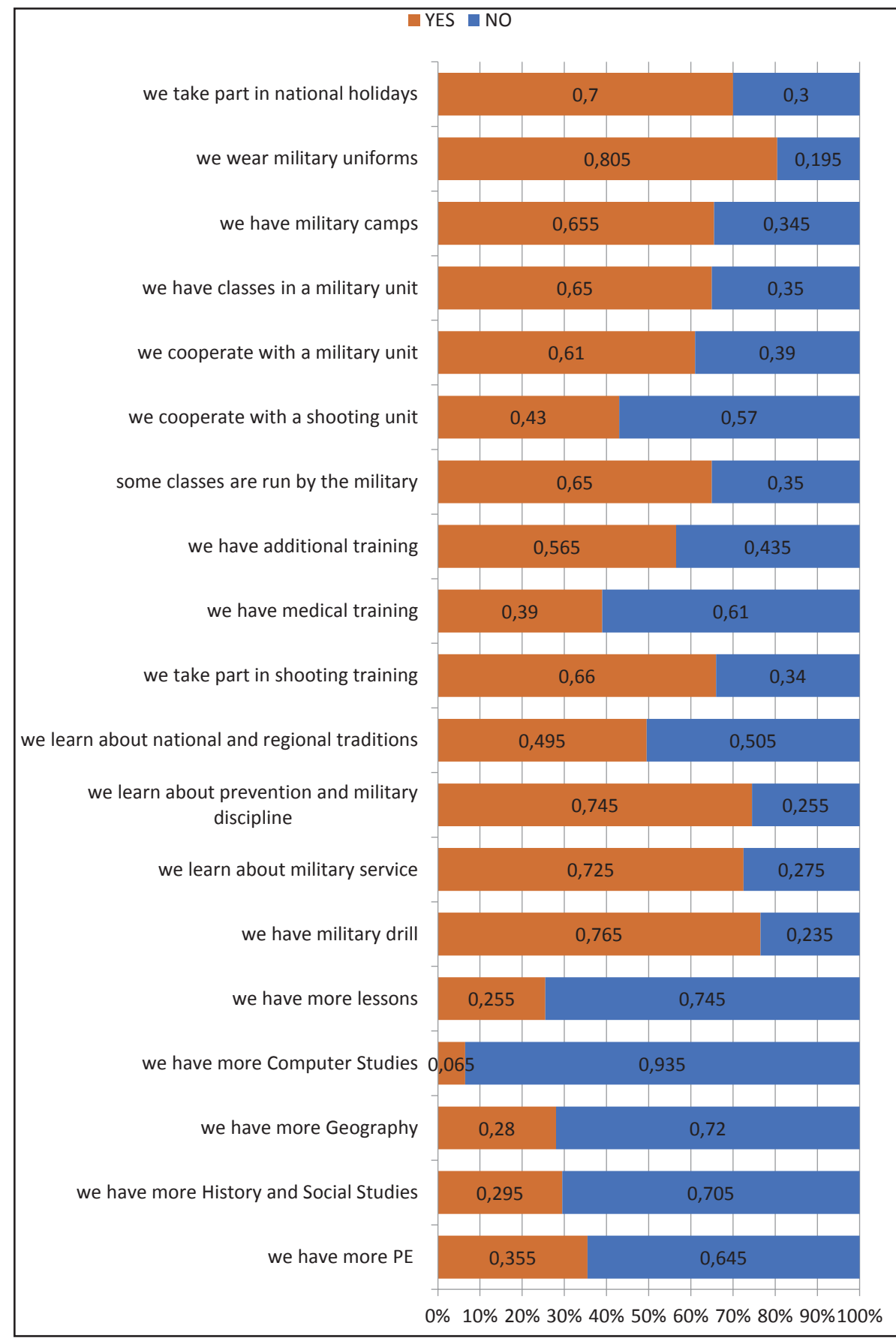

Fig. 5. Curriculum differences in military classes in comparison with classes of other profiles in the opinion of the surveyed students 
The surveyed students pointed out that they have an extra up: to 3 hours weekly $34.5 \%$, 4-6 hours weekly 46\% and more hours weekly 19.5\% ( Fig 6).

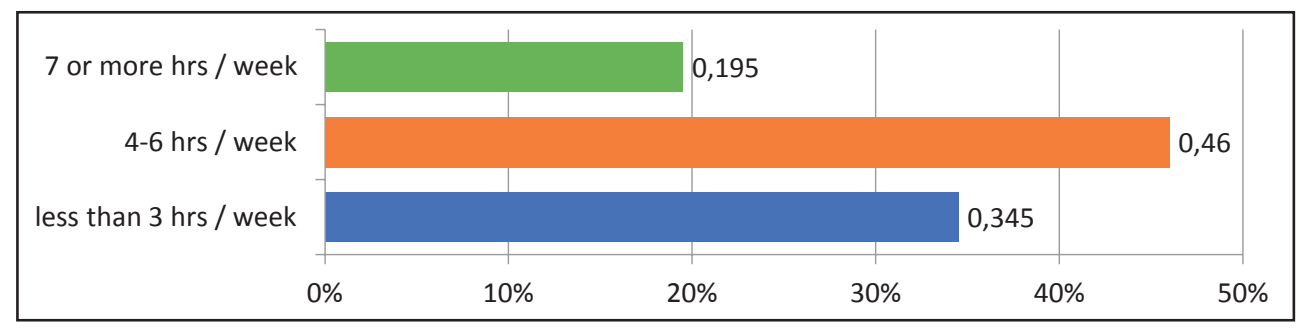

Fig. 6. Time for realisation of additional curriculum according to the surveyed students

The analysis of the results reveals that students of military classes also go to military units $70 \%$ and military camps; weekend camps $44 \%$, summer camps 50 \%, winter camps $14.5 \%$ ( Fig 7).

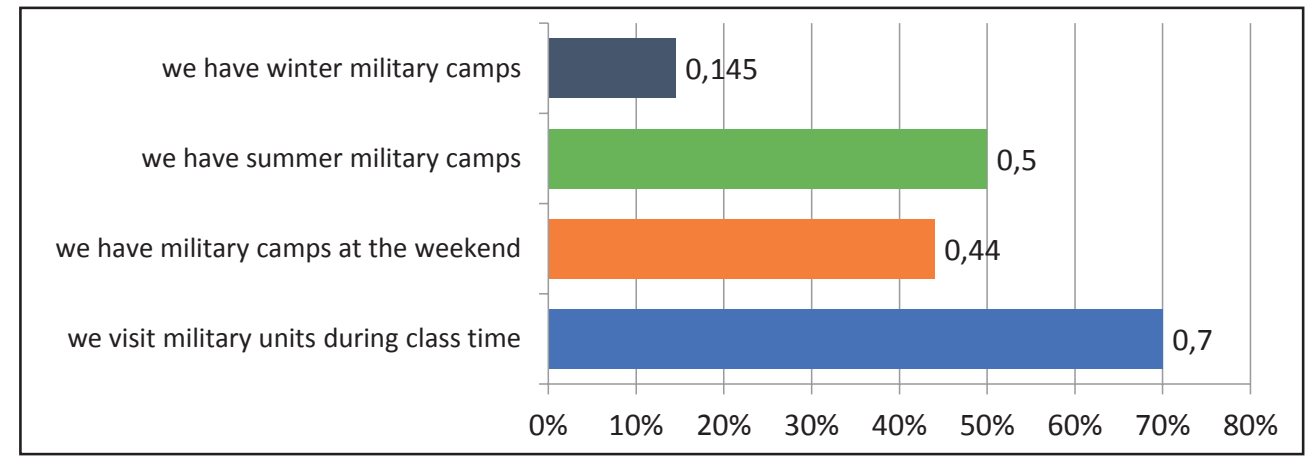

Fig. 7. Curriculum-related trips according to the surveyed students

\section{Objectives of curriculum in military classes according to the surveyed students}

During education in a military class, the surveyed students classified as highest: health and fitness $76 \%$, good conduct $66 \%$, helping other people $60 \%$, family happiness $53 \%$, work and commitment to family $49 \%$. In the middle were: work and economy $48 \%$, good marks $46 \%$, and social order $43 \%$. Lowest rated were: 
salvation of your soul $27 \%$, comfortable life $23 \%$, and recognition in the community $16 \%$. Some students noted they were not at all interested in salvation of their souls $18 \%$ and recognition in community $7 \%$ (Fig 8 ).

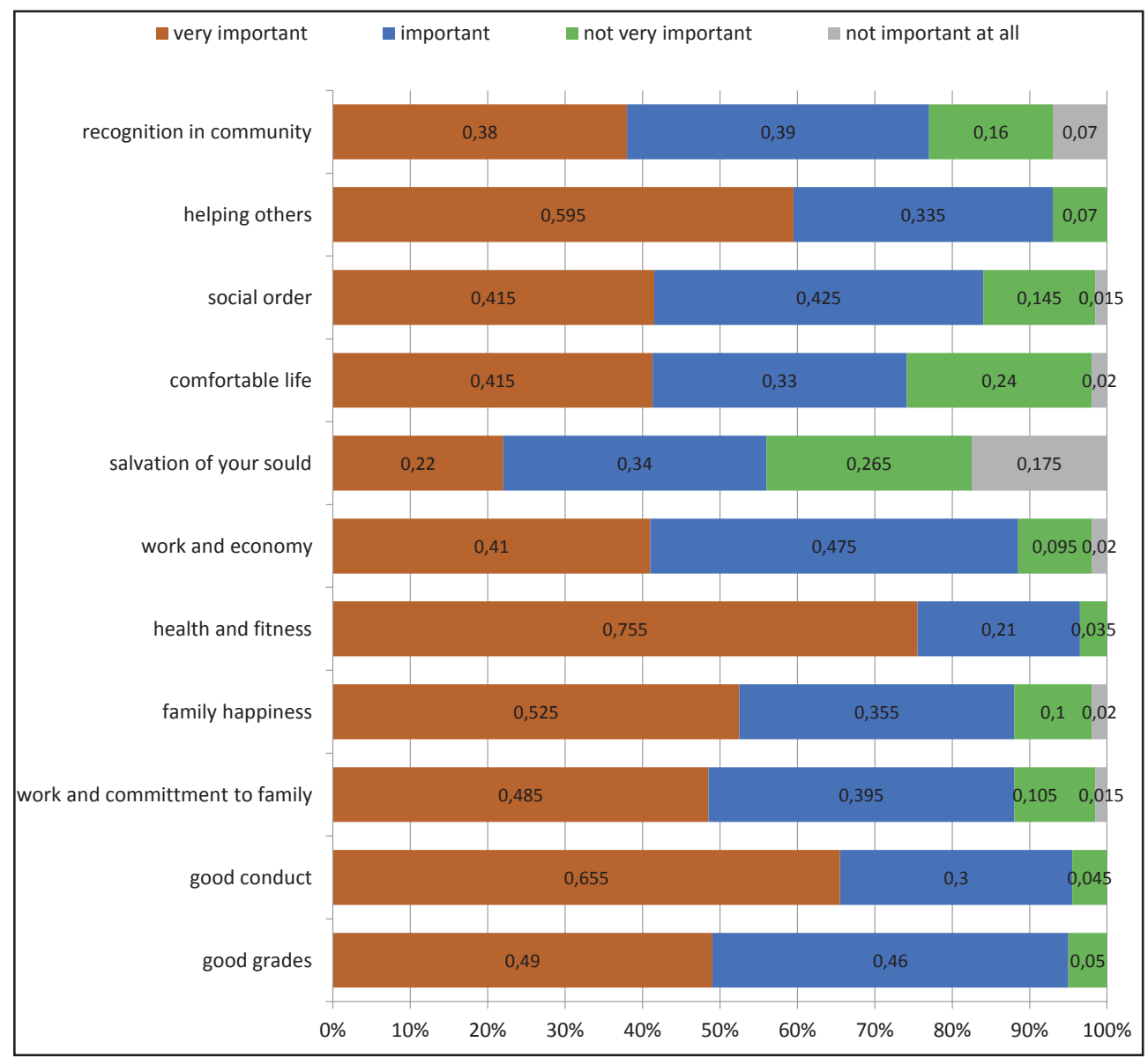

Fig. 8. Pursuits of students in the curriculum in a military class

The surveyed students of military classes were the most interested in achieving the objectives of their education in the range of: shooting $24 \%$, military drill $21 \%$, combat strategy and black tactics $18 \%$, military service $16 \%$, survival $13 \%$, weapons and military equipment $12 \%$, security and national defence $12 \%$, and patriotic national and regional traditions 8\% (Fig 9). 


\section{FIELD OF STUDIES}

shooting $24 \%$
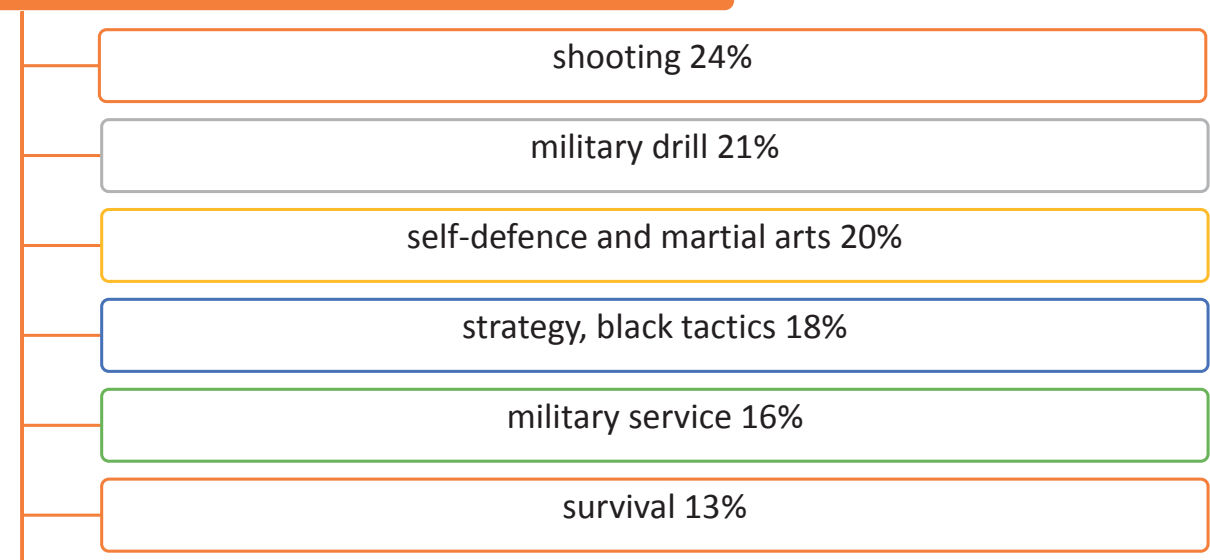

weapons and military equipment $12 \%$

security and national defence $12 \%$

patriotic national and regional traditions $8 \%$

discipline $5 \%$

medicine at combat scene $4 \%$

History, Social Studies, Geography 3\%

Computer Studies 3\%

police profile $3 \%$

sport 3\%

rescue team $2 \%$

Fig. 9. The areas of education in the curriculum favoured by military class students

The students thought that the skills they gain resulting from the aims of their education would be useful in further military service $48 \%$, for security and national defence $17 \%$, for various types of threats $15 \%$, for enrollment for higher studies 9\%, first aid for another person 8\%, and character education 8\% (Fig 10). 


\section{USE OF ACQUIRED SKILLS}

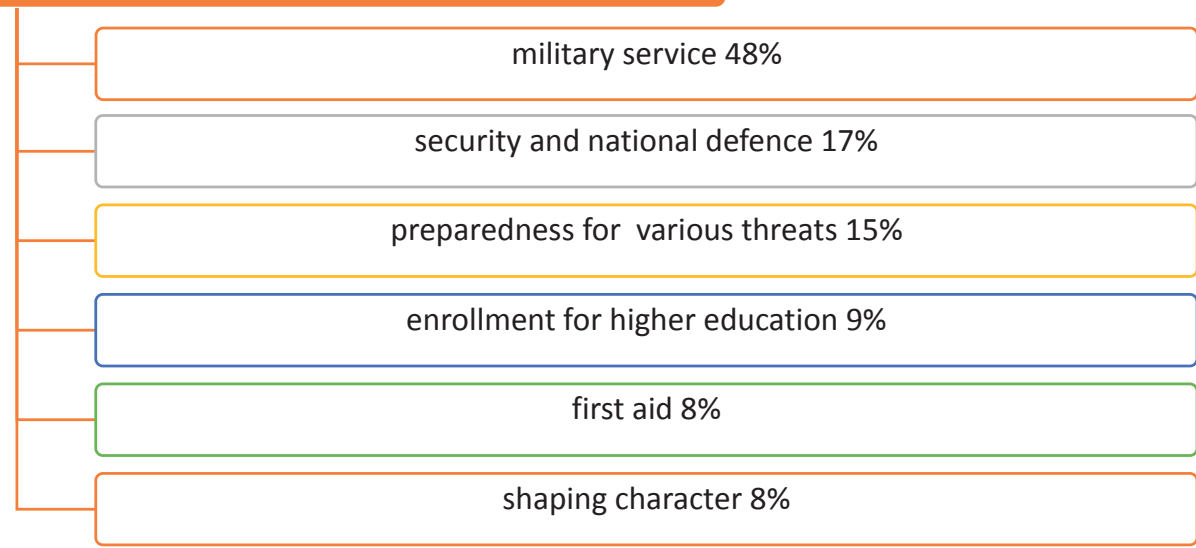

Fig. 10. The ways of applying skills gained by military class students

\section{The specific character of military class students learning according to the researched curriculums}

The surveyed students defined the criteria applied to recruitment in their school aimed at effective realisation of military curriculum. The scale of answers was as follows: average grade from selected subjects $76.0 \%$, result of junior secondary school final exam $75.5 \%$, grade for conduct on the final report from junior secondary school 74.0\%, medical examination $70.0 \%$, documented achievement and success in academic and sport, social, charity or culture related activity $65.5 \%$, physical fitness exam $56.0 \%$, and results of interview with the school representatives $50.5 \%$. The least important criterion was the date of application $36.5 \%$ (Fig 11). 


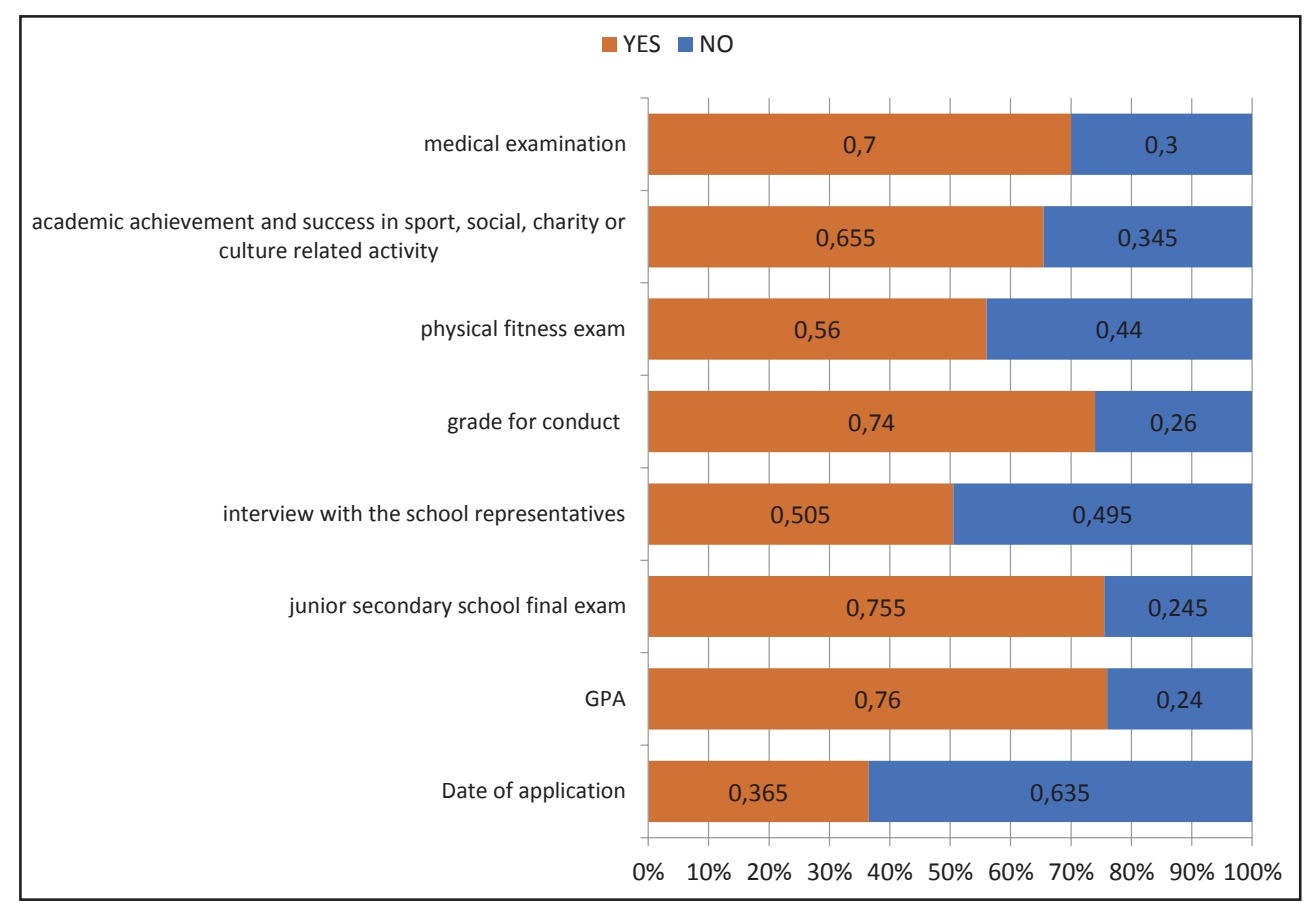

Fig. 11. The criteria used in schools during enrolment according to the surveyed students

The surveyed students rated learning in military classes (Fig 12). The graduates of military classes achieve high results in physical training $89 \%$ (I totally agree $59 \%$, I rather agree $30 \%$ ), show interest in defence and state security $83 \%$ (I totally agree $47 \%$, I rather agree $36 \%$ ), participate in military extra classes $76 \%$ (I totally agree $46 \%$, I rather agree $30 \%$ ) and sport $74 \%$ (I totally agree $37 \%$, I rather agree $37 \%$ ). 


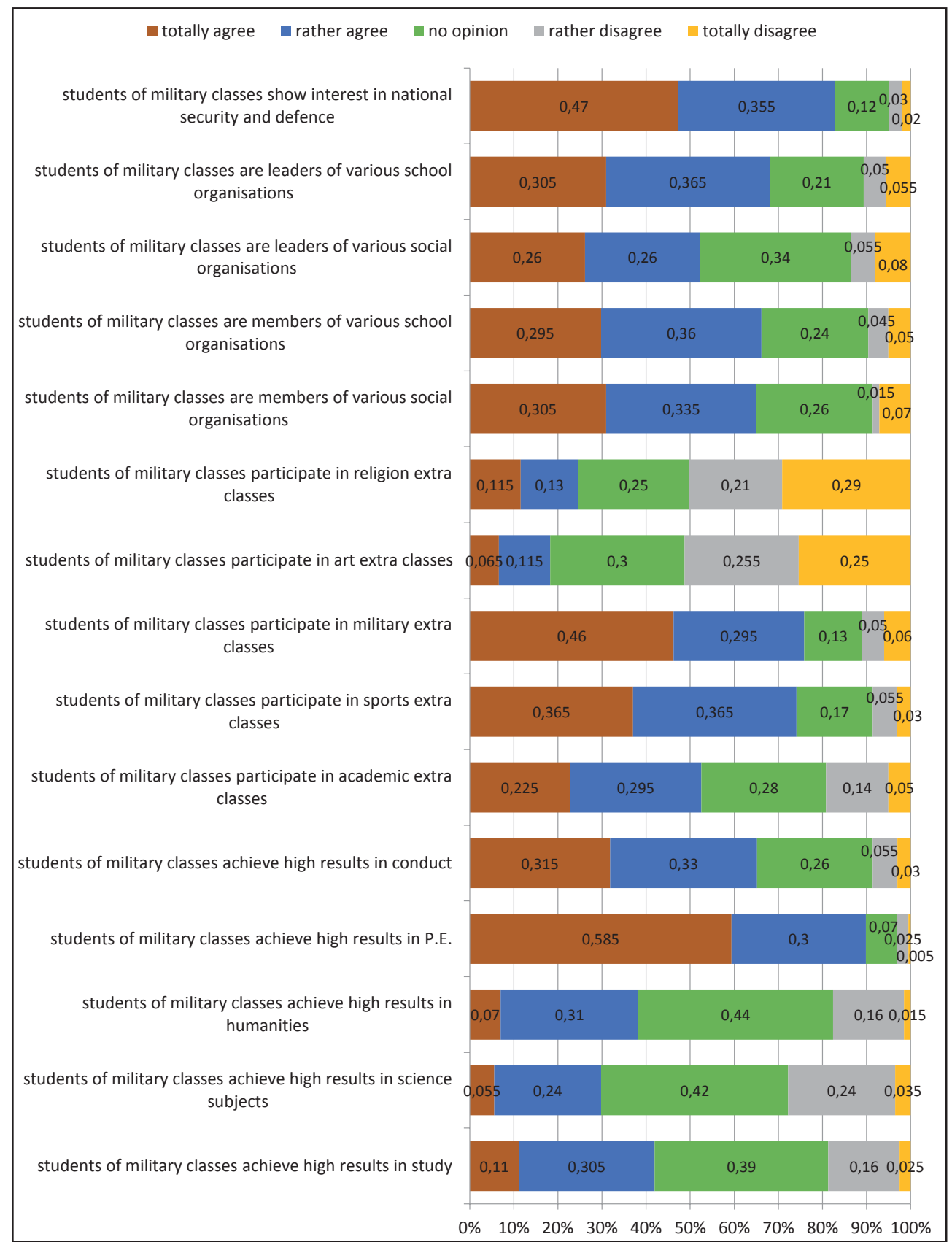

Fig. 12. Characteristics of students of military classes according to the surveyed students 
The analysis of the survey results indicates that military class students can be distinguished by social activity in the school environment: leadership 68\%, and membership $66 \%$ in various school organisations as well as in the local community: leadership $52 \%$ and membership $65 \%$ in various social organisations. Even though $65 \%$ of the surveyed students declared that military class students receive high grades in conduct, academic success was confirmed by $42 \%$ of the surveyed students and participation in extra subject classes was pointed out by $52 \%$ of the group. The success in high grades in the humanities was confirmed only by $38 \%$ of the surveyed students and $18 \%$ of them pointed out their absence. Even lower was the estimate of the uniformed students in science subjects- high results were confirmed by $30 \%$ of the surveyed students and denied by $28 \%$. According to the surveyed students, the least fitting profile for the military class student is participation in extra classes in religion and art - the answer "I rather do not agree" and "I totally disagree" was given respectively by $50 \%$ and $51 \%$ of the surveyed students.

The surveyed students applied the scope of the surveyed features of a military class student to themselves. The surveyed students confirmed high results in physical education $90 \%$ and participation in military classes $72 \%$ and sports extra classes $63 \%$. As in the general profile, religion and art did not enjoy much interest - 20\% and 23\% of surveyed students declared their participation. Most students were interested in national defence and security $83 \%$. Half of the surveyed students thought that they achieved high results in study $48 \%$, especially in humanities $55 \%$ and less often in science $33 \%$. They also indicated their participation in extra mural classes $60 \%$ and high grades in conduct $85 \%$. The assessment of personal academic achievement was slightly higher than for the military class students in general. More than half of the surveyed students confirmed their membership in various school organisations 55\% and social organisations $52 \%$. The leaders of those organisations were respectively $30 \%$ and $25 \%$ of the surveyed students (Fig 13). 


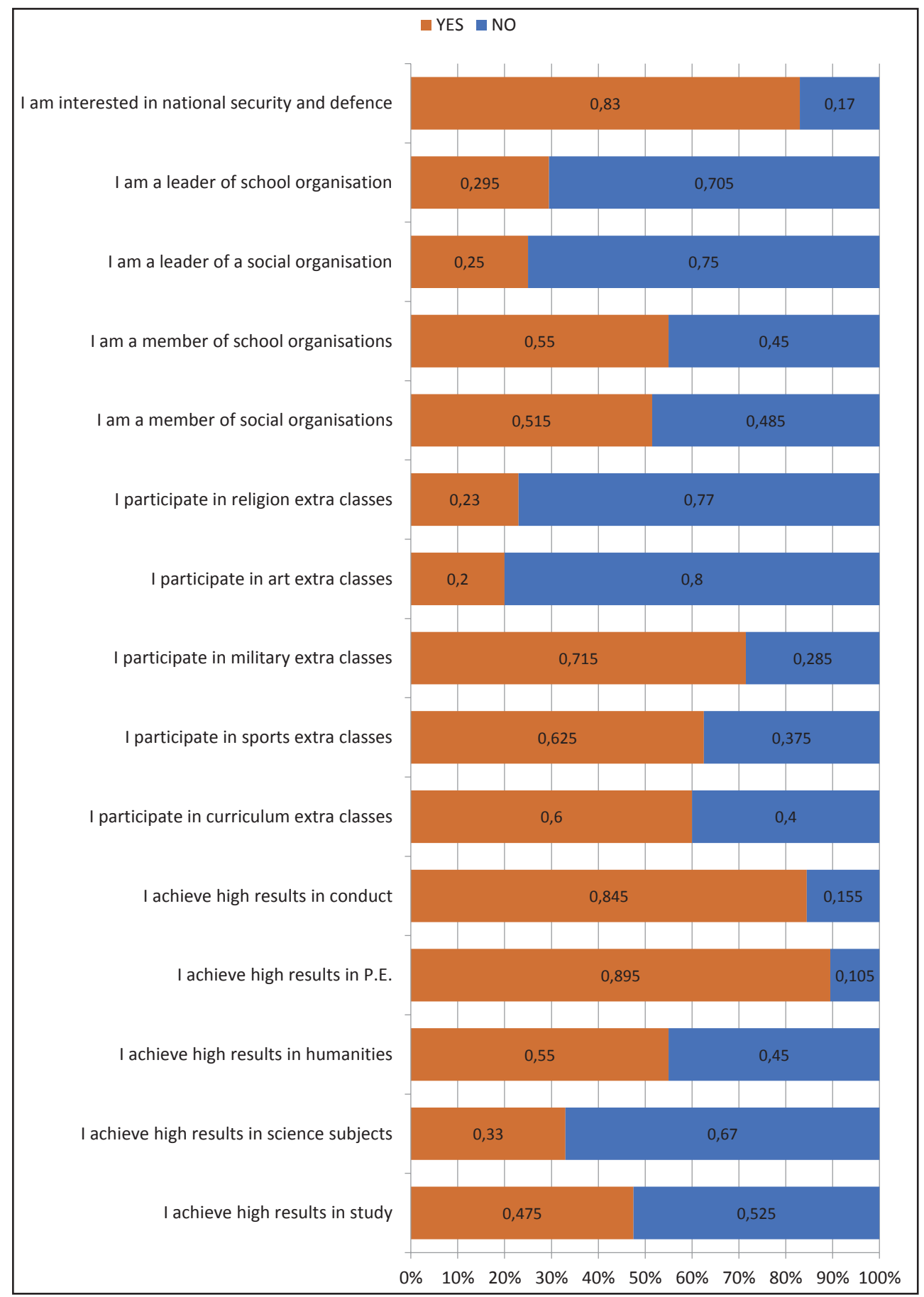

Fig. 13. Personal characteristics in the opinion of the surveyed students 
The synthesis of the collected results allows a profile of a military class student to be created (Fig 14).

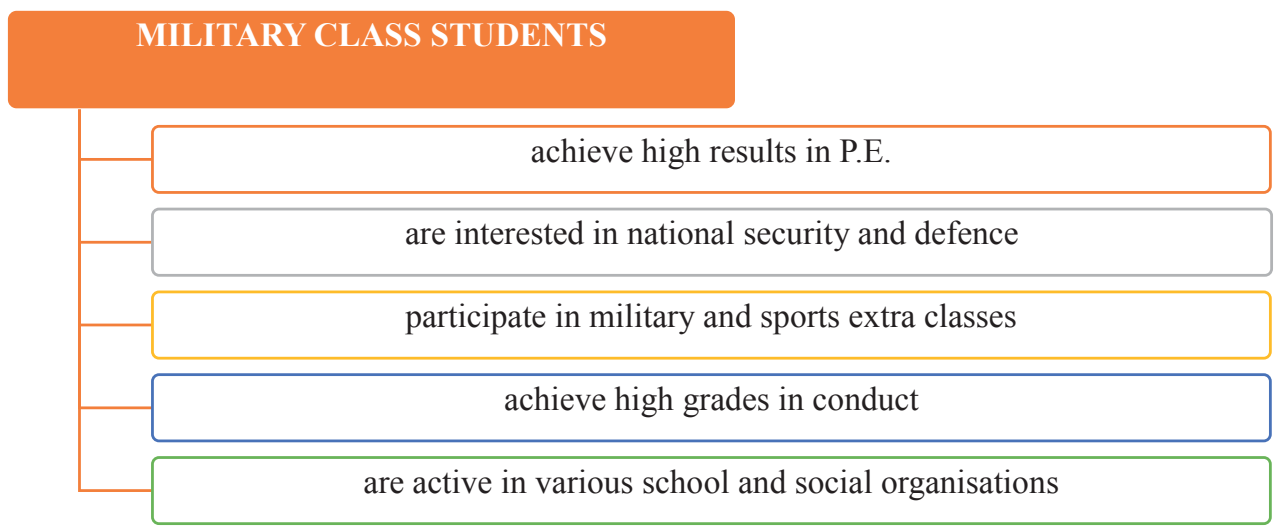

Fig. 14. Profile of a military class student in the opinion of the surveyed students

\section{Conclusions}

In the above article, preliminary characteristics of the curriculum in military classes were described based on the opinion of the students who participate in them. Analysis of the received results of the study allowed particular questions posed in the study to be answered.

1. What are the specific characteristics of curriculum in military classes in the opinion of the surveyed students?

The research proved that the curriculum in military classes in the opinion of the surveyed students includes many attributes such as: characteristic activities based on the defence-military dimension, educational content embracing elements of military training, school and extra mural classes (trips) with the objective of military education and the transmitted values and aims. The respondents also have some expectations from the institutions cooperating with military classes. According to the surveyed students of uniformed classes, what is characteristic for them is most of all wearing a uniform $80.5 \%$ and in the scope of education: classes in military drill $74.5 \%$, and education about military service $72.5 \%$. The surveyed students also pointed out that they participate in national festivities 
$70 \%$, shooting training $66 \%$, military camps $65.5 \%$ and classes in a military unit $65 \%$. Some lessons in military classes are conducted by the military $65 \%$. There is cooperation with a military unit $61 \%$ and a shooting unit $43 \%$. The students of uniformed classes learn about national and regional traditions $49.5 \%$. The curriculum includes additional training $56.5 \%$ and medical training 39\% more hours of physical training, 35.5\%, history and knowledge about society WOS $29.5 \%$, geography $28 \%$, IT $6.5 \%$. The surveyed students declared that they have more hours than classes with other profiles. The surveyed students declared that for realisation of the enumerated curriculum scope they have additionally up to 3 hours weekly $34.5 \%$, 4-6 hours weekly $46 \%, 7$ and more hours weekly 19.5.\%. The military class students $40 \%$, summer camps $50 \%$, and winter camps $14.5 \%$.

2. What are the aims of curriculum in military classes in the opinion of the surveyed students?

The analysis of results indicates that the highest in the hierarchy of aims of education in military classes were classified by students: health and fitness $76 \%$, good conduct $66 \%$, helping others $60 \%$, family happiness $53 \%$, work and commitment to family $49 \%$. The medium rank in their pursuit was attributed to such values as : work and good home management $48 \%$, good marks $46 \%$, and order in society $43 \%$. The lowest rank was attributed most often to: salvation of own soul 18\%, recognition in the society $7 \%$. The surveyed students of military classes were most interested in the lessons in: shooting $24 \%$, military drill $21 \%$, self-defence and martial arts $20 \%$, combat strategy and black tactics $18 \%$, military service $16 \%$, survival $13 \%$, weapons and military accessories $12 \%$, security and national defence $12 \%$, patriotic national and regional traditions $8 \%$, Students thought that the achieved skills would help them in further military service $48 \%$, for national defence and security $17 \%$, for various threats $15 \%$, for enrollment for higher studies $9 \%$, helping another person $8 \%$, and shaping their own character $8 \%$.

3. What are the characteristics of the students of military classes using the researched curriculums in the opinion of the surveyed students?

The students of military classes must fulfil certain criteria applied to enrolment into military classes in secondary schools. The study proved that the criteria for enrolment into military classes in secondary school are as follows: average grade from selected subjects $76,0 \%$, the result of final examination at junior secondary 
school 75.5\%, grade in conduct in junior secondary school report 74\%, medical examination 70\%, documented achievement and success in academic activity, sports, social activity, charity or cultural activity $65.5 \%$, physical fitness $56 \%$, and result of interview with the school representative $50.5 \%$.

The surveyed students rated young people in military classes. The graduates of military classes first of all achieve high results in physical training $89 \%$, they show interest in defence and state security $83 \%$, participate in military extra classes $76 \%$ and sport $74 \%$. The military class students are distinguished by social activity in school environment: leadership 68\%, and membership 66\% in various school organisations as well as leadership 52\% and membership 65\% in various social organisations in the local community. Even though $65 \%$ of the surveyed students declared that military class students achieve high grades in conduct, academic success was confirmed with $42 \%$ of the surveyed students and 52\% indicated participation in extra mural classes. The surveyed students applied the features disclosed in the survey of a military class student to themselves. The surveyed students confirmed high results in physical education $90 \%$ and participation in military classes $72 \%$ and sports classes $63 \%$. As in the general profile, religion and art did not enjoy much interest.

The analysis of the survey results shows that most students were interested in national defence and security $83 \%$. Half of the students thought that they achieved high results in study $48 \%$, especially in humanities $55 \%$ and less frequently in science $33 \%$. They also more often indicated their participation in extra mural classes connected with school subjects $60 \%$ as well as high grades in conduct $85 \%$. The assessment of personal academic achievement was slightly higher than the one for the military class students in general. More than half of the surveyed students confirmed their membership in various school organisations $55 \%$ and social organisations $52 \%$. The synthesis of the collected results allows a profile of a student of a military class to be created who can be distinguished by: achievement of high results in physical training, interest in defence and national security, participation in military and sports extramural classes, high grades in conduct, activity in various school and community organisations.

The following conclusions can be made from the study of curriculum in military classes: 
1. There is a need for preparation and conducting systematic study of military classes, especially their curriculum

2. It is necessary to analyse the results of research after 1990, especially pertaining to the paedagogical experiment carried out between 1998 and 2003 and enhance it with the experience of many secondary schools which have been carrying out extensive and ambitious military education programmes for years.

3. It seems also important to make an effort to create uniformed proposals for programme directives considering the need to create a background for the defensive potential of the Polish Republic more extensively.

\section{References}

Jakubowska, U., 1993. Czynności badawcze w psychologii i pedagogice. Zarys problematyki. Wydawnictwo Uczelniane WSP, Bydgoszcz.

Łobocki, M., 2006. Metody i techniki badań pedagogicznych. Impuls, Kraków.

Pilch, T. and Bauman, T., 2001. Zasady badań pedagogicznych. Strategie ilościowe i jakościowe. Wydawnictwo Akademickie Żak, Warsaw.

Urych, I. 2016. Military class in Poland - experiences and perspectives. Security and Defence Quarterly, 11(2), 112-134.

Urych, I. 2017. Students of military classes concerning selected aspects of Poland's national security. An empirical study. Security and Defence Quarterly, 17(4), 21-47.

Urych, I. 2017. Wartości uczniów klas wojskowych - analiza wyników badań. Zeszyty Naukowe ASzWoj, 109(4), 148-177.

Urych, I. and Kanarski, L., 2015. Możliwości budowania podstaw programowych dla klas mundurowych. In R. Bartkowski and W. Moczulski (eds) Edukacja dla bezpieczeństwa. Wspótpraca wojska i policji w budowie podstawy programowej. Stowarzyszenie Ruch Wspólnot Obronnych, Gniezno.

Szumski, J., 1999. Wstęp do metod i technik społecznych. Wydawnictwo Naukowe "Śląsk", Katowice. 